\title{
OSTI
}

OAK RIDGE

NATIONAL

LABORATORY

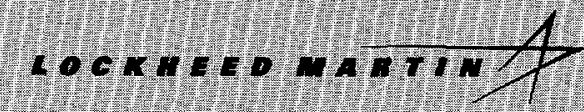

(1)

1. Whe

II)

程:

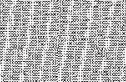

W.

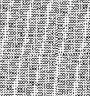

t.t.

1)

1)

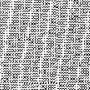

(3)

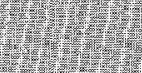

ORNL/MD/LTR-93 -

Level 2

\author{
R. N. Morris
}

DECEMBER 1997

Fissile Materials Disposition Program

This report was prepared as an account of work sponsored by an agency of the United States Government. Neither the United States Government nor any agency thereof, or any of their employees, makes any warranty, expressed or implied, or assumes any legal liability or responsibility for any third party's use or the results of such use, of any information, apparatus, product or process disclosed in this report, or represents that its use by such third party would not infringe privately owned rights. 


\section{Revision History}

\begin{tabular}{|c|c|c|}
\hline Revision Number & Date Issued & Reason for Revision \\
\hline 0 & December 1997 & \\
\hline
\end{tabular}




\section{DISCLAIMER}

This report was prepared as an account of work sponsored by an agency of the United States Government. Neither the United States Government nor any agency thereof, nor any of their employees, makes any warranty, express or implied, or assumes any legal liability or responsibility for the accuracy, completeness, or usefulness of any information, apparatus, product, or process disclosed, or represents that its use would not infringe privately owned rights. Reference herein to any specific commercial product, process, or service by trade name, trademark, manufacturer, or otherwise does not necessarily constitute or imply its endorsement, recommendation, or favoring by the United States Government or any agency thereof. The views and opinions of authors expressed herein do not necessarily state or reflect those of the United States Government or any agency thereof. 


\section{DISCLAIMER}

Portions of this document may be illegible electronic image products. Images are produced from the best available original document. 
ORNL/MD/LTR-93I

Level 2

Computational Physics and Engineering Division

MOX Capsule Post-Irradiation Examination

Vol II: Test Plan for 30-GWd/MT Burnup Fuel

Revision 0

R. N. Morris

December 1997

Concurred by: Stephen A. Hodge September 1997

Concurred by: Brian S. Cowell September 1997

Prepared by the Oak Ridge National Laboratory

Oak Ridge, Tennessee 37831-6418

managed by

LOCKHEED MARTIN ENERGY RESEARCH CORP.

for the

U.S. DEPARTMENT OF ENERGY

under contract DE-AC05-96OR22464 


\section{CONTENTS}

LIST OF FIGURES $\ldots \ldots \ldots \ldots \ldots \ldots \ldots \ldots \ldots \ldots \ldots \ldots \ldots \ldots \ldots \ldots \ldots$

LIST OF TABLES $\ldots \ldots \ldots \ldots \ldots \ldots \ldots \ldots \ldots \ldots \ldots \ldots \ldots \ldots \ldots \ldots \ldots$

LIST OF ACRONYMS $\ldots \ldots \ldots \ldots \ldots \ldots \ldots \ldots \ldots \ldots \ldots \ldots \ldots \ldots \ldots$ vii

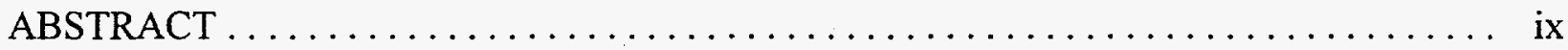

1. INTRODUCTION $\ldots \ldots \ldots \ldots \ldots \ldots \ldots \ldots \ldots \ldots \ldots \ldots \ldots \ldots \ldots \ldots \ldots$

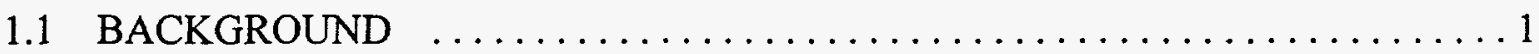

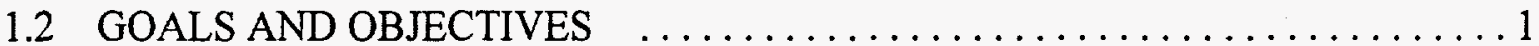

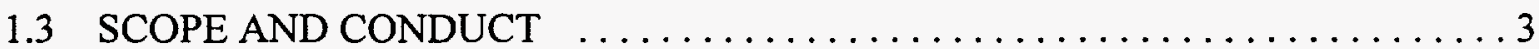

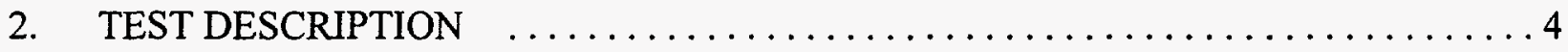

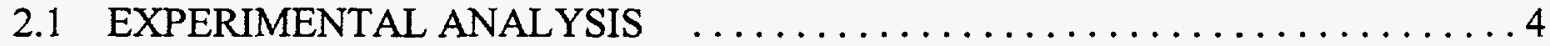

3. CAPSULE ASSEMBLY INSPECTION AND DISASSEMBLY $\ldots \ldots \ldots \ldots \ldots$

3.1 INITIAL CAPSULE INSPECTION $\ldots \ldots \ldots \ldots \ldots \ldots \ldots \ldots \ldots \ldots$

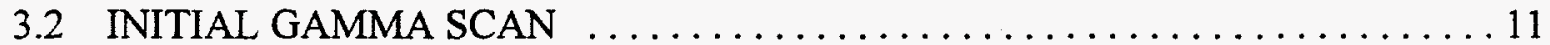

3.3 DISASSEMBLY OF THE CAPSULE ASSEMBLY AND THE

REMOVAL OF THE FUEL-PIN ASSEMBLY AND FUEL $\ldots \ldots \ldots \ldots \ldots \ldots$

3.4 VISUAL AND DIMENSIONAL INSPECTION OF THE FUEL

PELLETS OR FUEL-PIN SEGMENTS $\ldots \ldots \ldots \ldots \ldots \ldots \ldots \ldots \ldots \ldots \ldots \ldots$

3.5 FUEL-PIN SEGMENT NONDESTRUCTIVE GAMMA SCAN $\ldots \ldots \ldots \ldots \ldots$

3.6 PELLET SEGMENTING (OR CORING)

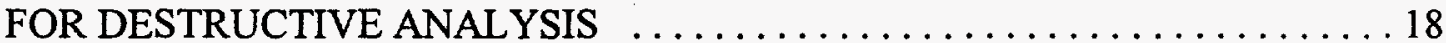

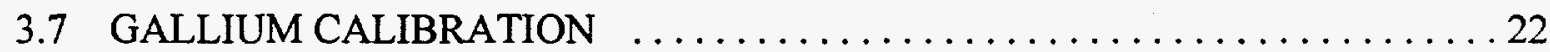

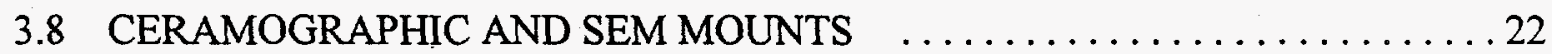

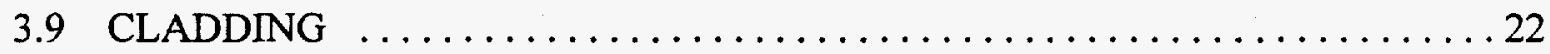

4. STORAGE OF CAPSULE CONTENTS $\ldots \ldots \ldots \ldots \ldots \ldots \ldots \ldots \ldots \ldots \ldots \ldots \ldots$

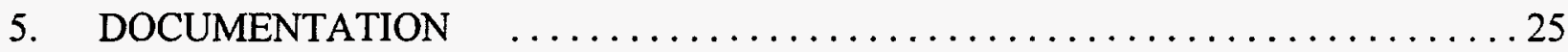

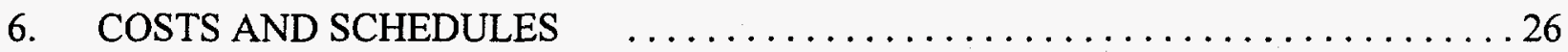

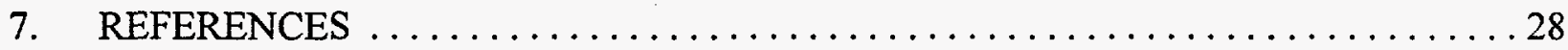




\section{LIST OF FIGURES}

Figure

Page

Test assemblies .5

General PIE task flow $\ldots \ldots \ldots \ldots \ldots \ldots \ldots \ldots \ldots \ldots \ldots$

3 Typical numbering system for capsule ID $\ldots \ldots \ldots \ldots \ldots \ldots \ldots \ldots$

4 Gamma-scanning illustration $\quad \ldots \ldots \ldots \ldots \ldots \ldots \ldots \ldots \ldots \ldots \ldots$

5 Schematic of capsule assembly opening $\ldots \ldots \ldots \ldots \ldots \ldots \ldots$

6 Diagram of a fission gas collection system $\ldots \ldots \ldots \ldots \ldots \ldots \ldots \ldots$

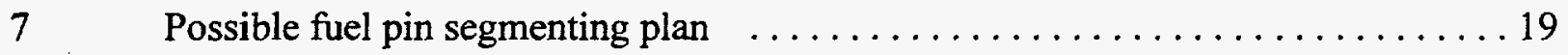

8 Options for cutting fuel and clad specimens $\ldots \ldots \ldots \ldots \ldots \ldots \ldots \ldots \ldots \ldots \ldots$

9 Pellet segmenting for radiochemistry $\ldots \ldots \ldots \ldots \ldots \ldots \ldots \ldots \ldots \ldots \ldots$

10 Cost and schedule for the $30-$ GWd/MT PIE $\ldots \ldots \ldots \ldots \ldots \ldots \ldots \ldots$ 


\section{LIST OF TABLES}

Table

Page

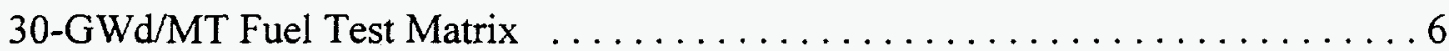

Relative Statistical-Uncertainty-vs-Estimated Effort .7

3

Destructive Fuel and Clad Sample Matrix 9

4

Fuel and Clad Analysis 10

5

Estimated PIE Costs .26 



\section{LIST OF ACRONYMS}

ES\&H Environment, Safety, \& Health

GWd/MT Gigawatt days per metric ton

ID Identification

IFEL Irradiated Fuels Examination Laboratory

LWR Light-water reactor

MOX Mixed oxide

MWd/MT Megawatt days per metric ton

NDE Nondestructive examination

PIE Post-Irradiation examination

SEM Scanning electron microscope 



\begin{abstract}
This test plan is a Level-2 document as defined in the Fissile Materials Disposition Program Light-Water Reactor Mixed-Oxide Fuel Irradiation Test Project Plan. The planned post-irradiation examination (PIE) work to be performed on the mixed uranium and plutonium oxide fuel capsules that have received burnups of approximately $30 \mathrm{GWd} / \mathrm{MT}$ is described. The major emphasis of this PIE task will be material interactions, particularly indications of gallium transport and interactions. This PIE will include gamma scanning, ceramography, metallography, pellet radial gallium analysis, and clad gallium analysis. A preliminary PIE report will be generated before all the work is completed so that the progress of the fuel irradiation may be known in a timely manner.
\end{abstract}




\section{INTRODUCTION}

\subsection{BACKGROUND}

The Fissile Materials Disposition Program Light-Water Reactor Mixed-Oxide Fuel Irradiation Test Project Plan details a series of test irradiations designed to investigate the use of weapons-grade plutonium in mixed-oxide (MOX) fuel for light-water reactors (LWR). ${ }^{1,2}$ Commercial MOX fuel has been successfully used in overseas reactors for many years; however, weapons-derived test fuel contains small amounts of gallium. A concern exists that the gallium may migrate out of the fuel, react with the clad, and thereby promote loss of fuel-pin integrity. No experimental evidence exists to determine the validity of this hypothesis.

To ensure that unexpected failure of the test capsules will not cause problems to the irradiation reactor, a set of capsules will be pulled from the reactor at burnups of approximately 8,000 and 20,000 MWd/MT and examined for indications of threats to the test capsule integrity. Volume I of this test plan details the planned examinations that will establish the extent, if any, of the fuel-pin degradation at the early and intermediate burnups. ${ }^{3}$ The goal of this $30,000-\mathrm{MWd} / \mathrm{MT}$ plan is to provide detailed information on the full-term exposure; as before, the primary interest is to determine if any gallium-driven interactions are occurring.,

The nomenclature for this task is as follows:

Test Assembly The entire assembly that is inserted into the reactor test position.

Basket Assembly The aluminum basket with shield that holds the capsules.

Capsule Assembly. The stainless steel capsule containing the fuel-pin assembly.

Fuel-Pin Assembly The sealed Zircaloy tube containing the MOX fuel.

The post-irradiation examination (PIE) will only involve the capsule assembly(ies) and the fuel-pin assembly(ies).

At the present time it is intended that the gallium profiles will be determined by cutting the pellet sample into small pieces, analyzing each small piece separately, and combining the data to infer the profile. If a more cost-effective method usable in a hot-cell environment is subsequently developed by the project, this plan may be modified to take advantage of the new technique.

\subsection{GOALS AND OBJECTIVES}

The goal of this task is to verify experimentally the presence or absence of material interactions in the MOX fuel test, to track any migration of the gallium, and to examine the fuel for unusual behavior. 
The objectives of this PIE task are the following:

1. Inspect, both visually and dimensionally the capsule assembly(ies) and, after removal from the capsule, the fuel-pin assembly(ies). Report any physical abnormalities, such as chemical attack, blisters, cracks, heavy or uneven oxide layers, weld failures, or clad distortions.

2. Gamma-scan the capsule assembly(ies) before opening to obtain nondestructive information on the relative burnup along the rod, any gross migration of fission products, large cracks in fuel pellets, and to verify that the fuel pellets have not shifted in the fuel-pin assembly, resulting in gaps in the pellet stack. Estimate the amount of swelling.

3. Puncture the end of the fuel pin after it has been removed from the capsule assembly and measure the fission gases. Measure both the pin pressure and the amount and composition of the fission gas.

4. Open the fuel-pin assembly in a way (segmented or split open) that best preserves the fuel pellets and clad for the desired examinations (the pellets are likely to have swelled and become locked in the clad.)

5. Inspect, both visually and dimensionally the fuel segments (as possible). Report any physical abnormalities, such as cracks, holes, friability, and distortions. Weigh the segments.

6. Gamma-scan selected fuel segments radially to obtain nondestructive information about burnup, fission-product distribution, and possible fission-product migration.

7. Cut up or core, dissolve, and perform radiochemical analyses on selected fuel segments so that information can be obtained about the radial distribution of gallium. Segmenting and radiochemistry will be the reference technique, but other methods, such as laser ablation and mass spectrometry, may also be used with or instead of radiochemical means if available and suitable for this task. Key fission products, uranium, and plutonium will also be measured and radially mapped.

8. Prepare mounts and conduct a ceramographic study of selected fuel segments.

9. Remove and prepare Zircaloy-clad specimens and metallographic mounts. Examine them for gallium surface deposition and gallium intrusion into the clad or capsule wall. Prepare and examine them with the SEM as activity levels permit. 
10. Perform tensile and hardness testing on selected clad specimens.

11. Prepare a preliminary PIE report that can be used by the project to confirm the capsule integrity at the end of irradiation.

12. prepare a comprehensive PIE report.

\subsection{SCOPE AND CONDUCT}

This document describes the generic sequence of steps, procedures, and decision points for the PIE examination of the capsule and its inner fuel-pin assembly at the planned burnup of 30 GWd/MT. The ORNL project office will be consulted before work begins to ensure that the most recent plans are being followed. Detailed procedures for the PIE work will be written prior to the performance of the subtask and will be approved before use. The major PIE work will be done in the Irradiated Fuels Examination Laboratory (IFEL), Building 3525. Radiochemistry work will be done in other ORNL facilities as necessary. Work will be conducted under the Quality Management Plan for Metals and Ceramics Division Non-Reactor Nuclear Facilities, QAP-X-MC-HC-01, Rev 0 . All work will be done under the appropriate facility ES\&H guidelines and will fall under the Metals and Ceramics Division Conduct of Operations, MET-ESH-SOP-2. 


\section{TEST DESCRIPTION}

The test assembly consists of nine capsule assemblies in three stacks contained in the basket assembly. Each capsule assembly is essentially a small stainless steel containment surrounding the fuel-pin assembly, a sealed Zircaloy cladding holding the MOX fuel pellets that contain varying amounts of gallium. The fuel-pin assembly contains 15 fuel pellets and a spring; the Zircaloy tube is sealed at both ends by welded plugs.

The close-fitting stainless steel tube that comprises the capsule assembly has special welded end fittings that serve as both handling and alignment guides. The capsule assembly is approximately $9.6 \mathrm{in}$. long; the fuel stack is $6 \mathrm{in.}$ long. The assemblies are shown in Fig. 1.

Table 1 details the fuel pellet types that will receive an exposure of $30 \mathrm{GWd} / \mathrm{MT}$. In addition, two other capsules, with an exposure of approximately $22 \mathrm{GWd} / \mathrm{MT}$, will be available for this PIE task ( 7 fuel pins total); depending on the outcome of this and previous irradiations, full or partial examinations of the 22-GWd/MT capsules may be included in the task as additions or substitutions. This baseline PIE plan considers only the five $30-\mathrm{GWd} / \mathrm{MT}$ test capsules.

The fuel pin assembly design is very simple, having no purge gas flow, thermocouples, or dosimeters. The basket assembly includes separate locations for dosimeters that will be handled separately from the capsules. Information on the irradiation history of a particular capsule assembly will be provided to the PIE effort by other sources.

\subsection{EXPERIMENTAL ANALYSIS}

In its most basic form this test constitutes a one-variable, two-level factorial experiment; gallium is the variable and was present at two concentrations in the plutonium feed from which the two test fuels were made. Based upon this, the examination of only two capsules, one low-gallium capsule and one high-gallium capsule, would satisfy the minimum analysis requirement; however, practical realities dictate that four of the five capsules, two low-gallium and two high-gallium should be examined because the irradiation conditions, while similar, are not exactly the same. Difficulties of handling specimens in the hot-cell environment make a limited amount of redundancy desirable. Thus, this plan is based on the examination of four capsules, with the fifth being treated as a spare.

The actual gallium content of the two test fuels will be known prior to the irradiation of the test capsule. If the gallium content is not significantly different between the two test fuels, then only those capsules containing fuel thermally treated for gallium removal will undergo the full destructive examination. This decision will be made by the ORNL test project office. 


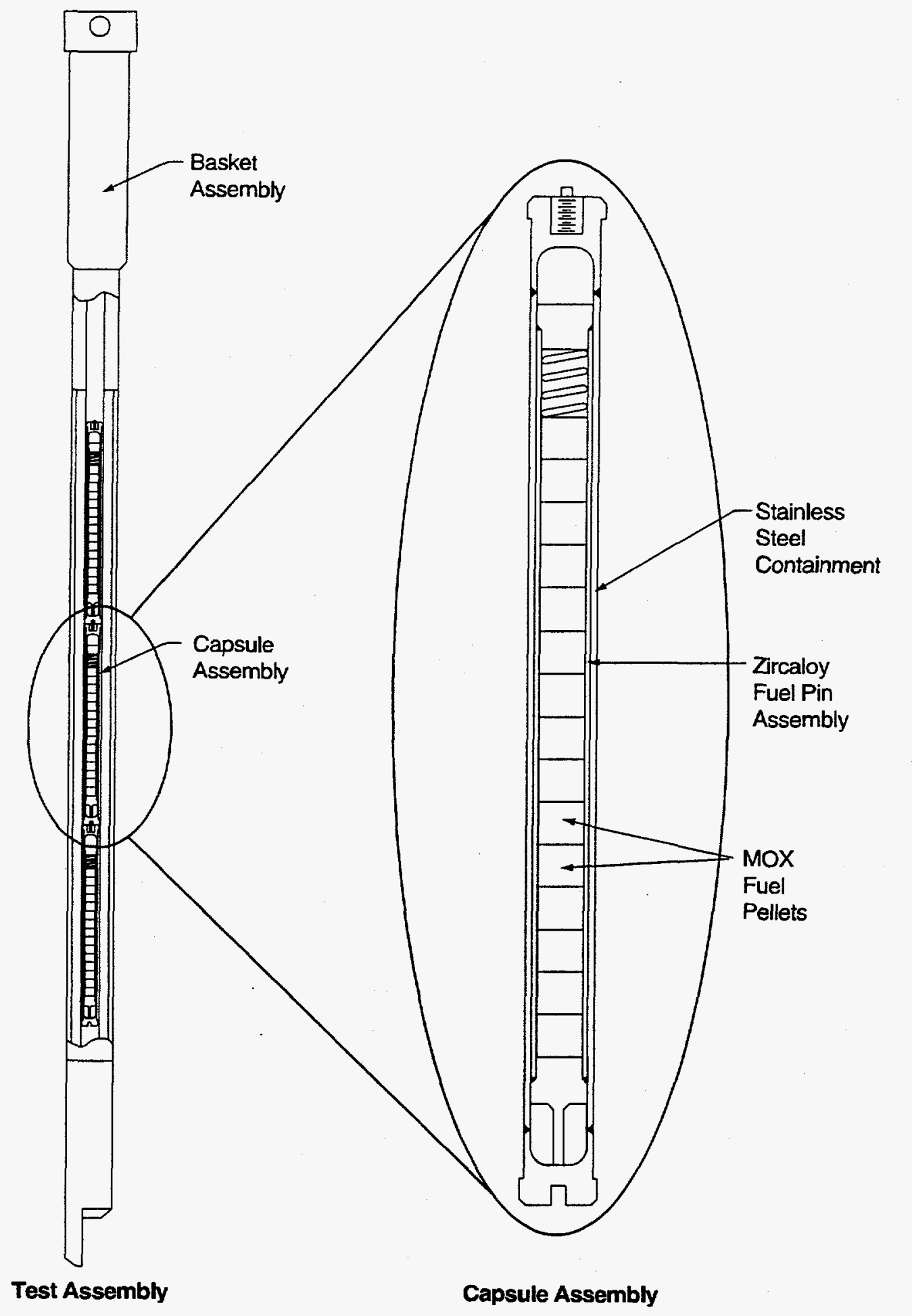

Fig. 1. Test assemblies. 
Table 1. 30-GWd/MT fuel test matrix

\begin{tabular}{|c|c|c|c|c|}
\hline $\begin{array}{l}\text { Fuel } \\
\text { Type }\end{array}$ & $\begin{array}{c}\text { Description } \\
\text { (Each MOX Fuel Pin } \\
\text { Contains 3.75 g Pu) }\end{array}$ & $\begin{array}{l}\text { Feed } \\
\text { Stock }\end{array}$ & $\begin{array}{c}\mathrm{Pu} \\
\text { Purification }\end{array}$ & $\begin{array}{l}\mathrm{Pu} \text { to } \mathrm{PuO}_{2} \\
\text { Conversion }\end{array}$ \\
\hline Test $1 \mathrm{C}$ & \multirow{5}{*}{$\begin{array}{c}5 \% \text { Weapons-Grade } \\
\text { Pu MOX }\end{array}$} & \multirow{5}{*}{$\begin{array}{l}1 \% \mathrm{Ga} \\
\text { Weapons } \\
\text { Grade Pu }\end{array}$} & \multirow{3}{*}{ None } & \multirow{5}{*}{ Hydride } \\
\hline Test 1D & & & & \\
\hline Test 1E & & & & \\
\hline Test 2C & & & \multirow[t]{2}{*}{ Thermal } & \\
\hline Test 2D & & & & \\
\hline
\end{tabular}

A related issue is the number of clad specimens to be machined from the fuel pins for the mechanical testing. For statistical purposes one would like as many as possible, but the high cost of preparation and the limited amount of material available demand that the sample size be modest. Because the uncertainty in computed statistical quantities varies as

$$
\frac{1}{\sqrt{N-1}} \text {, }
$$

we can roughly determine the best sample size in the absence of specific data by weighing uncertainty against estimated effort based on historical experience. Table 2 shows a rough comparison between relative uncertainty and effort.

Eight samples (four per fuel pin of a given gallium concentration) appear to be the optimum goal. To do much better would require at least twice as many samples because of the inverse-square-root dependence. This is probably unrealistic considering the small size of the fuel pins and the high cost of preparation and testing. When actual data are available, confidence interval estimators may be used to get a better idea of the actual uncertainty, but the point to be made here is that approximately eight clad mechanical specimens of each gallium exposure (four per capsule) is a cost-and materials-effective target. This number of samples is likely to be sufficient to reveal a significant gallium effect, but the reader should also realize that the sample size is too small to make definitive judgements about minor changes in clad properties.

Applying the same logic to the radiochemistry and ceramography produces an optimum goal of four samples per fuel pin as well. Fission gas measurements, spring and plenum gallium analysis, and visual inspections will be based on one measurement per fuel pin. 
Table 2. Relative statistical uncertainty vs estimated effort

\begin{tabular}{|c|c|l||}
\hline $\begin{array}{c}\text { Number of } \\
\text { Samples per } \\
\text { Ga Level }\end{array}$ & $\begin{array}{c}\text { Relative } \\
\text { Uncertainty } \\
\text { (Est.) }\end{array}$ & \multicolumn{1}{c|}{ Effort } \\
\hline \hline 2 & 1.00 & $\begin{array}{l}\text { Easiest; one sample per fuel pin. Handling (loading, } \\
\text { opening, cutting, etc.) costs may dominate analysis costs. }\end{array}$ \\
\hline 4 & 0.58 & $\begin{array}{l}\text { Twice as much work as the 2-sample case for a factor of 1.7 } \\
\text { improvement. Handling time and costs are estimated to be } \\
\text { comparable to analysis time and costs. Sufficient material } \\
\text { is available to repeat testing should problems arise. This } \\
\text { may be the minimum practical effort situation. }\end{array}$ \\
\hline 8 & 0.38 & $\begin{array}{l}\text { Four times as much work as the 2-sample case for a factor } \\
\text { of 2.6 improvement. Fuel-pin segments will be roughly } \\
\text { 0.2 in. thick. No significant handling problems expected. } \\
\text { Analysis costs and time are expected to dominate the } \\
\text { schedule. }\end{array}$ \\
\hline 16 & 0.26 & $\begin{array}{l}\text { Considerably more difficult and expensive than the } \\
\text { 8-sample case; many thin samples. Estimated schedule is } \\
\text { roughly twice that of the 8-sample case. Improvement } \\
\text { factor of 3.8 for 8 times as much work may not be cost } \\
\text { effective. }\end{array}$ \\
\hline
\end{tabular}




\section{CAPSULE ASSEMBLY INSPECTION AND DISASSEMBLY}

The destructive fuel and clad sampling matrix is shown in Table 3. Samples will be taken as needed from the available fuel pins. Table 4 details the overall planned fuel and clad analysis.

The general expectation is that the capsule assemblies will survive the irradiation intact and that the fuel pin can be removed from the stainless steel capsule by slitting on opposite sides. The fuel and clad specimens will be obtained by sectioning the fuel pin either in a transverse or an axial manner, depending on the sample shape desired. Should the fuel perform other than expected during irradiation, modification of this plan will be necessary. Fractured pellets may make radial gallium measurements difficult or impossible.

The remaining sections detail the generic subtask based on a favorable irradiation and a straightforward sectioning of the fuel pin. In all cases detailed procedures will be written for the operation and the project office will be consulted as unforeseen circumstances may dictate. A flow diagram of the PIE is shown in Fig. 2.

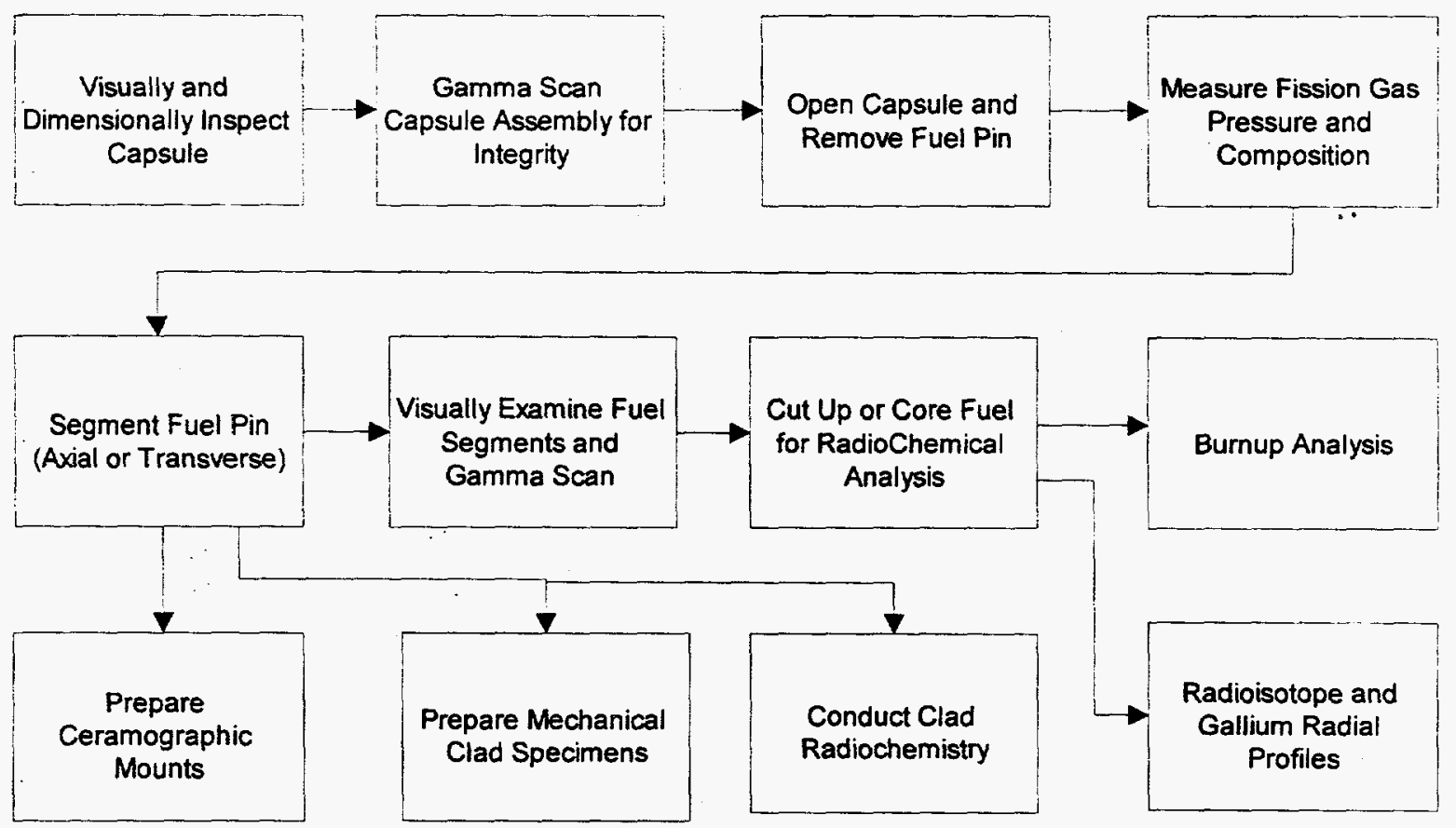

Fig. 2. General PIE flow. 
Table 3. Destructive fuel and clad sample matrix

\begin{tabular}{|c|c|c|}
\hline Sample Type & Sample Location & Operation \\
\hline \multirow{3}{*}{ Fuel Pin } & \multirow{3}{*}{ N/A } & Visual Examination \\
\hline & & Dimensional Measurements; Mass \\
\hline & & Fission Gas Measurements \\
\hline \multirow{5}{*}{$\begin{array}{l}\text { Fuel Segment } \\
\text { (Segment may be } \\
\text { either an axial or } \\
\text { transverse cut } \\
\text { through the fuel pin) }\end{array}$} & \multirow{5}{*}{$\begin{array}{l}\text { Various axial regions } \\
\text { along the fuel pin }\end{array}$} & Visual Examination \\
\hline & & Dimensional Measurements; Mass \\
\hline & & Gamma Scanning \\
\hline & & $\begin{array}{l}\text { Radial Pu, U, Fission Product; Gallium } \\
\text { Analysis }\end{array}$ \\
\hline & & Ceramography (SEM Possible) \\
\hline \multirow{4}{*}{$\begin{array}{l}\text { Clad Specimen } \\
\text { (Specimen may be a } \\
\text { Fuel Pin axial cut, a } \\
\text { transverse cut, or a } \\
\text { machined test } \\
\text { specimen) }\end{array}$} & \multirow{4}{*}{$\begin{array}{l}\text { Various axial regions } \\
\text { along the fuel pin }\end{array}$} & Metallography (SEM Possible) \\
\hline & & Tensile Test \\
\hline & & Hardness Test \\
\hline & & Gallium Analysis \\
\hline $\begin{array}{l}\text { SS capsule inner } \\
\text { surface }\end{array}$ & $\begin{array}{l}\text { Central region of } \\
\text { capsule }\end{array}$ & $\begin{array}{l}\text { Gallium Analysis (if there are } \\
\text { indications of clad damage) }\end{array}$ \\
\hline $\begin{array}{l}\text { Spring and upper } \\
\text { fuel pin }\end{array}$ & $\begin{array}{l}\text { Plenum region of fuel } \\
\text { pin }\end{array}$ & Gallium Analysis \\
\hline
\end{tabular}

\subsection{INITIAL CAPSULE INSPECTION}

The capsule assembly(ies) will be loaded into the IFEL North Hot Cell by following the standard operating procedures for loading objects into and out of the cell. The facility manager will be consulted if an unusual situation arises. Once the capsule assembly has been loaded into the North Hot Cell it will be transferred to the West Hot Cell using the in-cell electromechanical manipulator when disassembly is ready to begin. 
Table 4. Fuel and clad analysis

\begin{tabular}{|c|}
\hline $\begin{array}{l}\text { Planned Analysis - Four capsules total, } 30 \mathrm{GWd} / \mathrm{MT}, 2 \text { of each gallium concentration to } \\
\text { be used; the fifth will be a spare. } \\
\text { Note: Two other capsules of } 22 \mathrm{GWdMT} \text { will be available. The project may wish to examine them to a limited } \\
\text { extent, depending on the irradiation performance of previous capsules. }\end{array}$ \\
\hline Capsule Visual and Dimensional Inspection ( 4 capsules) \\
\hline Capsule Gamma Scan (4 capsules) \\
\hline Fuel Pin Inspection (4 fuel pins) \\
\hline Fuel Pin Fission Gas Measurement ( 4 fuel pins) \\
\hline $\begin{array}{l}\text { Fuel [Segments] Visual and Dimensional Inspections as Possible ( } 4 \text { samples from each fuel } \\
\text { pin, } 8 \text { low-gallium, } 8 \text { high-gallium, } 16 \text { total) }\end{array}$ \\
\hline $\begin{array}{l}\text { Gamma-Scan Fuel Segment ( } 4 \text { samples from each fuel pin, } 8 \text { low-gallium, } 8 \text { high-gallium, } \\
16 \text { total) }\end{array}$ \\
\hline Ceramography ( 4 samples from each fuel pin, 8 low-gallium, 8 high-gallium, 16 total) \\
\hline Fuel SEM (Option on selected samples if radiation levels are tolerable) \\
\hline $\begin{array}{l}\text { Cut up or Core Fuel Segments for Radiochemical Analysis ( } 4 \text { Fuel Segments from each } \\
\text { Fuel Pin, } 5 \text { cores per segment, } 20 \text { cores per pin, } 40 \text { low-gallium cores, } 40 \text { high-gallium, } \\
\text { cores, } 80 \text { cores total) }\end{array}$ \\
\hline Clad Metallography (4 samples from each fuel pin, 8 low-gallium, 8 high-gallium, 16 total) \\
\hline Clad SEM (Selected samples from Metallography) \\
\hline $\begin{array}{l}\text { SS Capsule Gallium Analysis ( } 4 \text { Capsule Sections, } 1 \text { from each capsule - used as indicator } \\
\text { of gallium attack on containment if clad is damaged) }\end{array}$ \\
\hline Spring and Plenum Gallium Analysis ( 1 from each fuel pin, 4 total) \\
\hline $\begin{array}{l}\text { Cut up Clad for Radiochemical Analysis ( } 4 \text { samples from each fuel pin, } 8 \text { low-gallium, } 8 \\
\text { high-gallium, } 16 \text { total) }\end{array}$ \\
\hline $\begin{array}{l}\text { Tensile Test Specimens ( } 4 \text { samples from each fuel pin, } 8 \text { low-gallium, } 8 \text { high-gallium, } 16 \\
\text { total) }\end{array}$ \\
\hline $\begin{array}{l}\text { Hardness Test Specimens ( } 4 \text { samples from each fuel pin, } 8 \text { low-gallium, } 8 \text { high-gallium, } 16 \\
\text { total) }\end{array}$ \\
\hline
\end{tabular}


Before any work is done, the test engineer will locate and record the identifying marks on each capsule assembly; if no marks are present, the engineer will mark the capsule assemblies so that their identity can be maintained. A typical numbering system is shown in Fig. 3. The project will document the ID method and the ID numbers of the test capsules before PIE begins.

The PIE will begin by visually inspecting the capsule assemblies for physical abnormalities such as blisters, cracks, unusual or heavy oxide layers, weld failures, or distortions. Any abnormality and its location on the capsule assembly will be recorded by video recorder and/or photographs, along with logbook entries. Storing the data in a digital format is encouraged for ease of manipulation and dissemination. Should any major problem be noted such as breeched containment, broken welds, or large physical distortions, the project manager will be consulted before proceeding with further PIE tasks. Each capsule assembly is to be weighed, and its mass recorded in the PIE logbook.

The capsule will be checked for bowing. If bowing exists, the disassembly method will be reviewed to determine if the distortion will cause handling problems; if so, the project office will be consulted before proceeding.

The length of the capsule assembly from end to end will be measured. The diameter of the capsule assembly will also be measured at a minimum of four equally spaced longitudinal locations. Each diameter measurement will consist of at least two measurements, $90^{\circ}$ apart, so that an out-of-round condition may be detected. The outside of the capsule will also be checked for variations of diameter along its length "bambooing" to provide an indication of pellet-clad mechanical interactions.

All measurements will be recorded in the PIE logbook and on a digital medium for easy transfer to other members of the PIE group; any physical problems, such as gross distortion, that may interfere with the removal of the fuel-pin assembly from the stainless steel capsule will be reported to the project office immediately so that the situation may be evaluated and future PIE work modified as necessary.

\subsection{INITIAL GAMMA SCAN}

After the initial visual and dimensional inspections have been completed, the capsule assembly will be mounted on the in-cell gamma scanner and gamma scanned from one end of the fuel column to the other. The scanner will be moved in sufficiently small increments such that any gaps of 0.030 in. or greater may be observed. The gamma scan will determine the axial activity of the capsule which can then be used to infer the internal mechanical integrity and to determine if any gross asymmetries in burnup or fission-product distribution exist. Since flexibility exists in the equipment and the exam is nondestructive, details concerning the gamma scanning can be determined or modified during the performance of the task. 
ORNL-DWG 97-2774 EFG
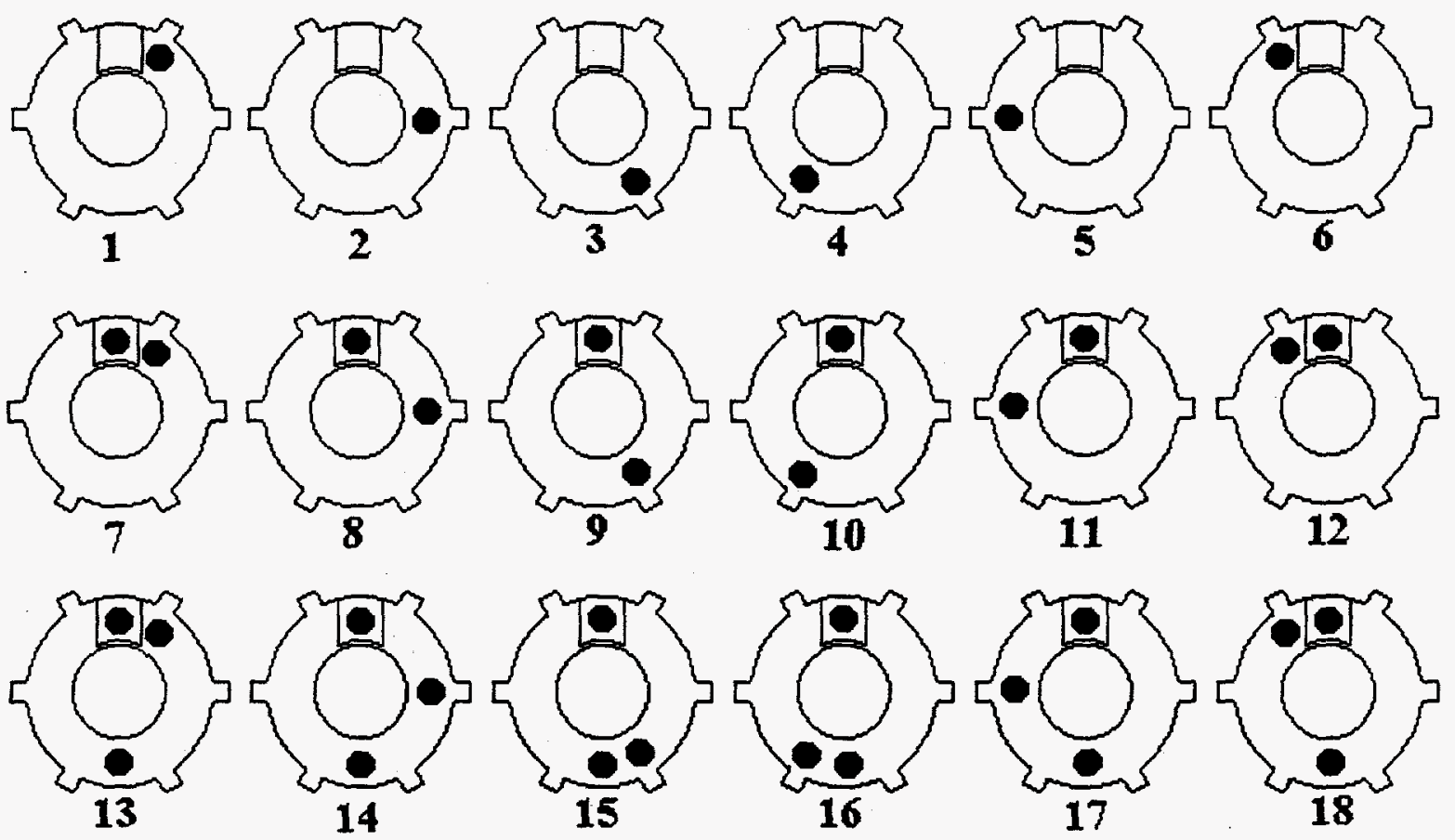

Fig. 3. Typical numbering system for capsule ID. 
An attempt will be made to measure the ${ }^{85} \mathrm{Kr}$ activity in the plenum region of the fuel pin to gain an indication of the fission gas release that can be compared with the puncture measurements. This measurement, if successful, can provide a nondestructive useful indication of the fission-gas-release fraction. ${ }^{6}$

Once the scan is complete, an axial map of the relative activity of the fission products can be constructed. The concept is shown schematically in Fig. 4. This map may be used to determine the spacing of the fuel pellets, provide an indication of fuel pellet cracks, estimate relative burnup, and determine if any gross migration of the fission-products has occurred. If there are indications of a serious problem, such as cracked fuel or massive fission-product migration, the project manager will be consulted before proceeding. These signs might indicate that the fuel was damaged during irradiation so that disassembly procedures would require revision. 
The object to be scanned is mounted on a 2-axis table and moved so that the point of interest is in the line of sight of a collimated gamma detector. By moving the table in a predetermined way, an entire region can be scanned. Both general acthily and specific

isotopes can be examined this way.

Note: The detector and its hardware are located on the outside of the hot cell; the sliding table and the object to be scanned are located on the inside of the hot cell.

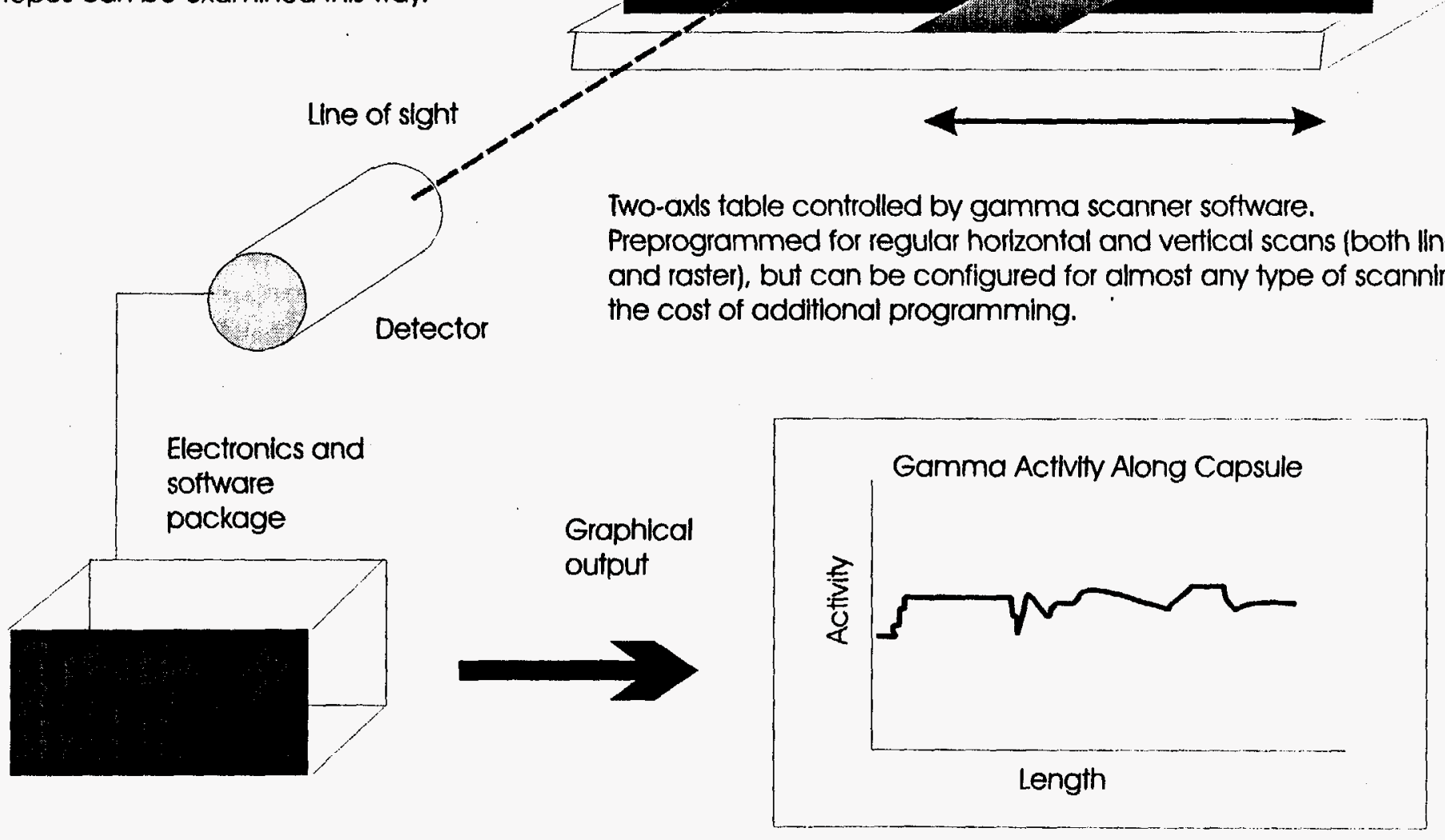

Fig. 4. Gamma-scanning illustration 


\subsection{DISASSEMBLY OF THE CAPSULE ASSEMBLY AND THE REMOVAL OF THE FUEL-PIN ASSEMBLY AND FUEL}

After the results of the gamma scanning have been evaluated, the capsule assembly will be moved to a working position in the West Hot Cell and a cutoff tool or an end mill used to cut off the top end to expose the fuel pin. The capsule weld may be used as a guide. Likewise, the bottom end of the capsule may be cut off, taking care not to cut into the pedestal. (See Fig. 5).

At this point, the ID on the top of the fuel pin should be recorded and checked against the expected number. Any differences should be immediately brought to the attention of the project management. After deburring the cut ends of the capsule, an attempt should be made to slide the fuel pin out of the capsule body. Sliding the fuel pin out of its stainless steel containment will prove successful only if clearances remain between the fuel pin and the capsule. If this is not the case, the fuel pin will have to be cut out of the capsule body.

To cut the fuel-pin assembly out of the capsule, it must be clamped in a fixture and a longitudinal cut made in the containment at two locations $180^{\circ}$ apart. The fixture should be carefully set up and the cuts made in multiple passes to minimize any scoring of the Zircaloy clad. Once the cuts have been made, the containment halves may be pried away from the fuel pin. The design of the fixture is the responsibility of the test engineer, and it will be designed after the capsule assembly as-built drawings are available. This jig is likely to be the same as the one used for the 8-and 20-GWd/MT PIEs.

Once the fuel pin has been removed from the capsule assembly, it may be examined both dimensionally and visually. In addition to the usual dimensional measurement, the fuel pin will be examined for variations in its diameter along its length (bambooing) to determine if pellet-clad mechanical interactions have taken place. The pin's weight and any unusual characteristics will be recorded.

After the fuel pin NDE inspections have been completed, the fission-gas measurements can be taken; the gas pressure and gas composition are of interest. Mass spectrometry, gas chromatography, and gamma spectrometry may be used as appropriate for the measurement. See Fig. 6 for a diagram of a fission-gas measurement device. The major drawback to such a system is the ratio of the volume of the device hardware to that of the fuel pin. A large volume ratio makes accurate absolute pressure measurements difficult. The small plenum volume and small fuel loading per pin limits the accuracy of this measurement. This technique, along with others, will be investigated to determined the likely measurement error before proceeding to ensure that the measurement is cost and schedule effective.

Since the fuel is expected to swell and become locked in the clad, segmenting the fuel is probably the only option for fuel examination. Slitting the clad and pulling it from the fuel stack may be useful for obtaining clad specimens and freeing individual pellets. Before cutting the fuel pin into segments, it is recommended that the end containing the spring be cut off first. The major problem will be the integrity of the fuel. If it is very friable, sectioning may be difficult. 

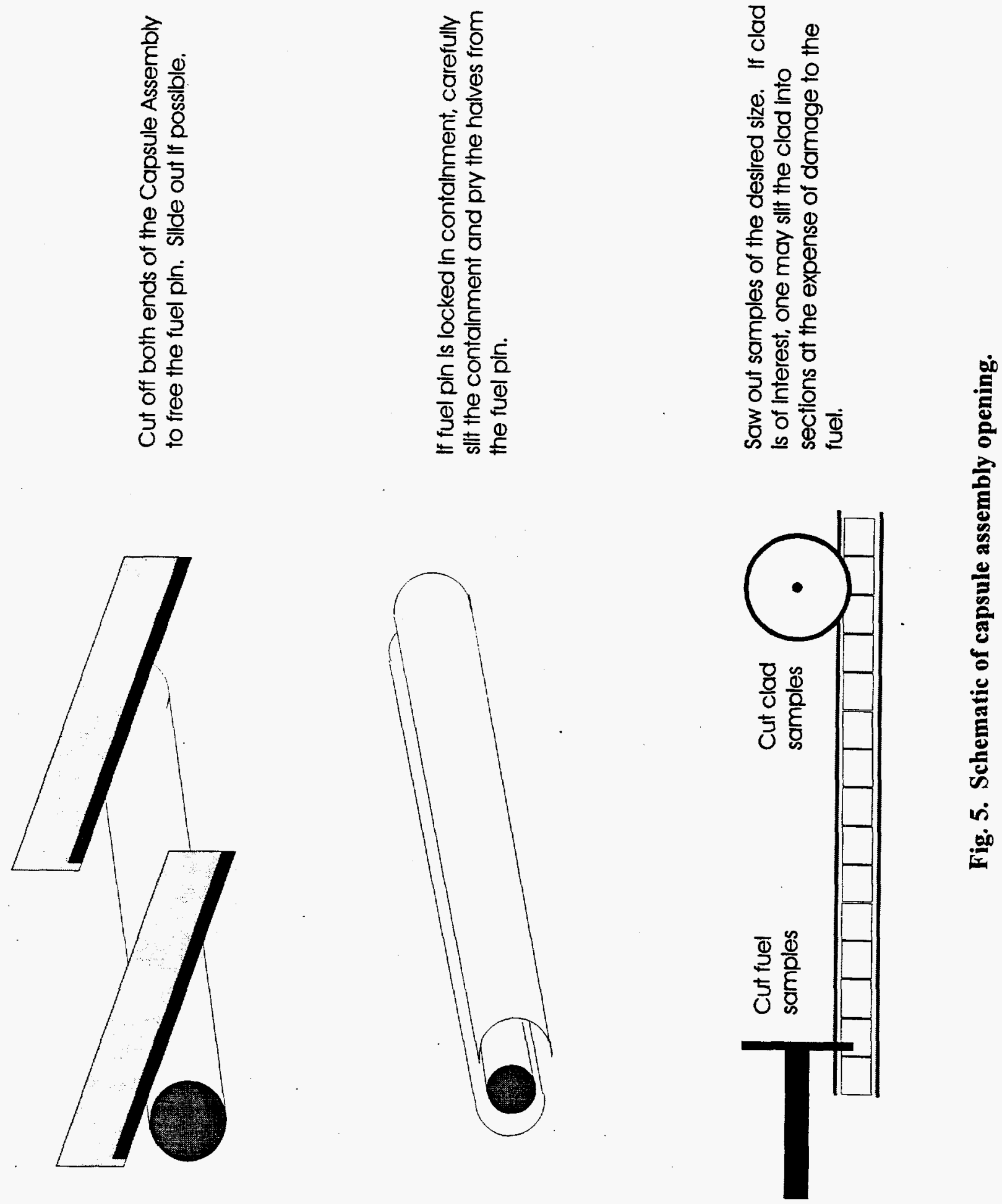
Gas line to collection chamber, mass spectrometer, gas

Puncture device chromagraph, gamma such as a pin, drill, or laser

Pressure gauge or transducer spectrometer, etc.

Working volume - as small as practical

Fuel pin

Fig. 6. Diagram of a fission-gas collection system. 
If the primary interest is in the clad or if full-length pellets are desired, longitudinal cuts can be made into the clad and the clad removed as strips from the stack of pellets. It is likely that some pellet damage will occur with this technique, but it may be acceptable if long-clad test samples are required. See Fig. 7 for a possible segmenting of the fuel pin and Fig. 8 for clad sampling options.

\subsection{VISUAL AND DIMENSIONAL INSPECTION OF THE FUEL PELLETS OR FUEL-PIN SEGMENTS}

Each fuel segment will be individually inspected for cracks, holes, friability, and distortions. Interactions with the clad will be noted. Swelling of the pellet will be estimated if the pellet is free or has been cut from the clad. In addition, a video record or photograph of each pellet or fuel pin assembly segment will be made and a particular record made of any abnormalities. An estimate of the mass of the clad and/or containment material will be made so that this mass may be subtracted from the total to determine the mass of the fuel.

\subsection{FUEL PIN SEGMENT NONDESTRUCTIVE GAMMA SCAN}

The fuel-pin segment will be prepared and mounted in the gamma scanner and radially scanned from edge to edge, passing through the center, in steps of approximately 0.060 in. with a collimator of approximately 0.060 in.; this procedure will result in data at about 5 to 8 radial locations. Recordings will be made of at least two fission products, one that represents a volatile chemical species and one that represents a nonvolatile species. This information will be stored in a digital format.

The ratios of fission products will be examined to determine if significant migration of isotopes has occurred. If unusual or surprising results are obtained, the project manager will be consulted before proceeding with further destructive analyses. If thin samples are used (fuel-pellet segments) the possibility of absolute calibrations and burnup calculations will be investigated.?

\subsection{PELLET SEGMENTING (OR CORING) FOR DESTRUCTIVE ANALYSIS}

Before proceeding with the destructive operations on the pellets, the personnel doing the radiochemical analysis will be consulted to determine the optimal sample size, specific contaminations of concern, and any other specialized aspect of the downstream activities. After reviewing the state of the pellets and the in-cell equipment, a determination will be made as to whether the operation is to be performed by cutting the pellet into pieces or by coring the pellet with special core drills. The candidate pellet or fuel pin assembly segment will be cut lengthwise into strips along the diameter or will be cored along the desired radii. (See Fig. 9).

The size of the strips or holes will be determined by the resolution desired and resources available. Each sample will be weighed before further processing, and steps will be taken to avoid 


\section{Fuel Pin Segmenting for Specimen Generation}

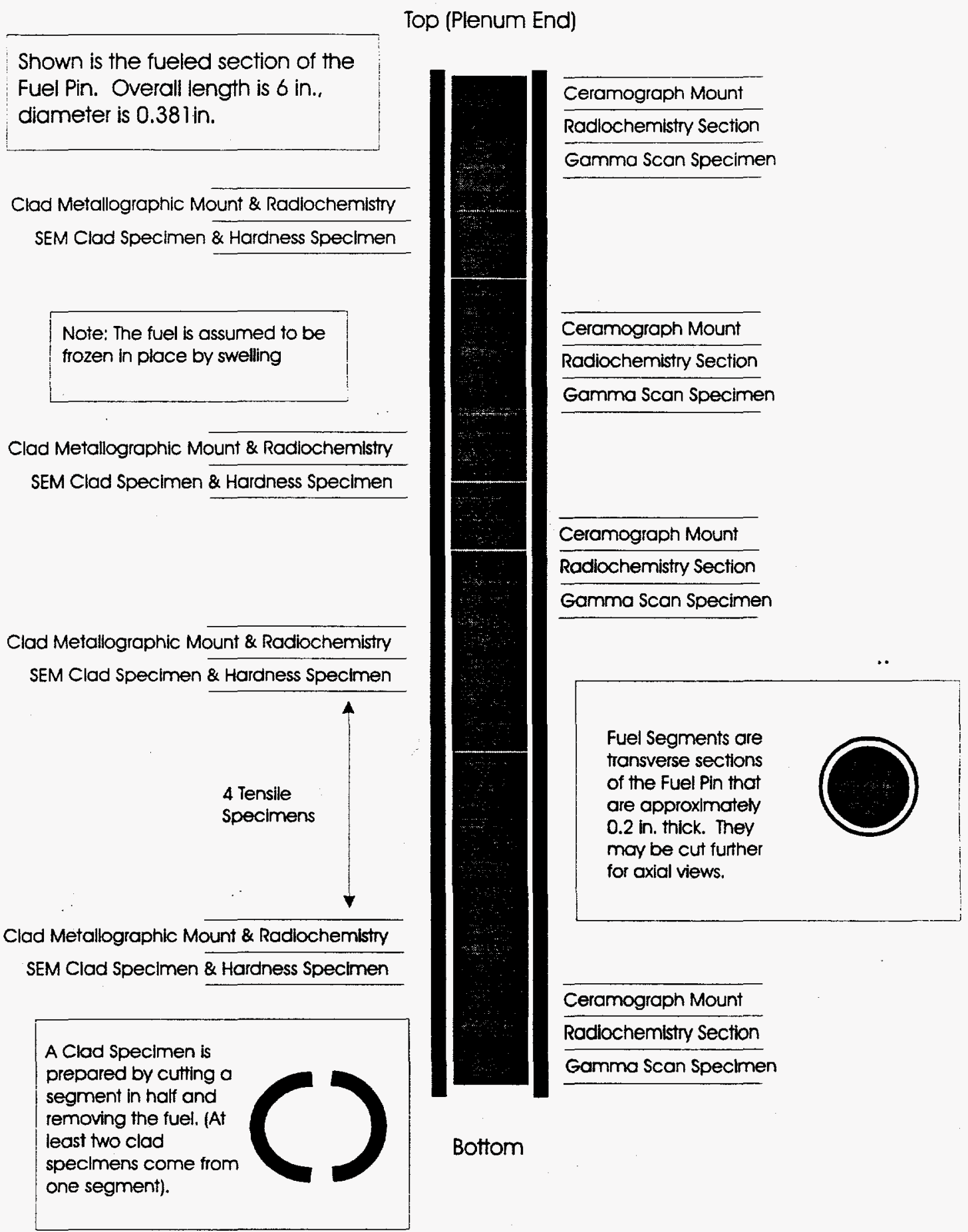

Fig. 7. Fuel pin segmenting plan. 


\section{Fuel Segments}

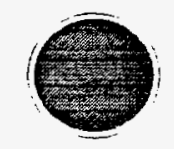

Transverse

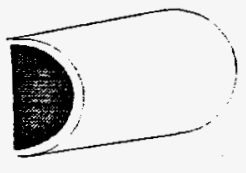

Axial

\section{Clad Specimens}
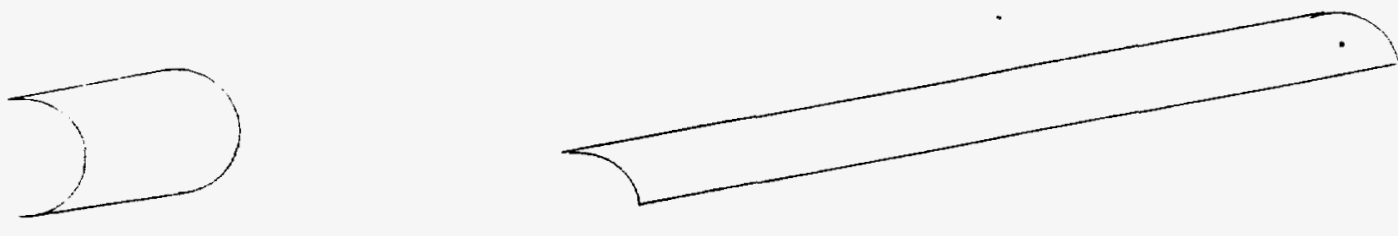

Transverse

Axial

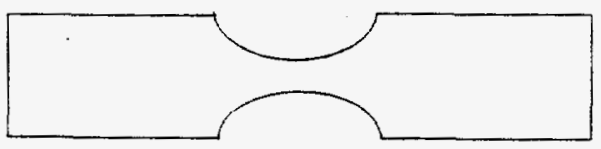

Tensile Test Specimen

Fig. 8. Options for cutting fuel and clad specimens. 


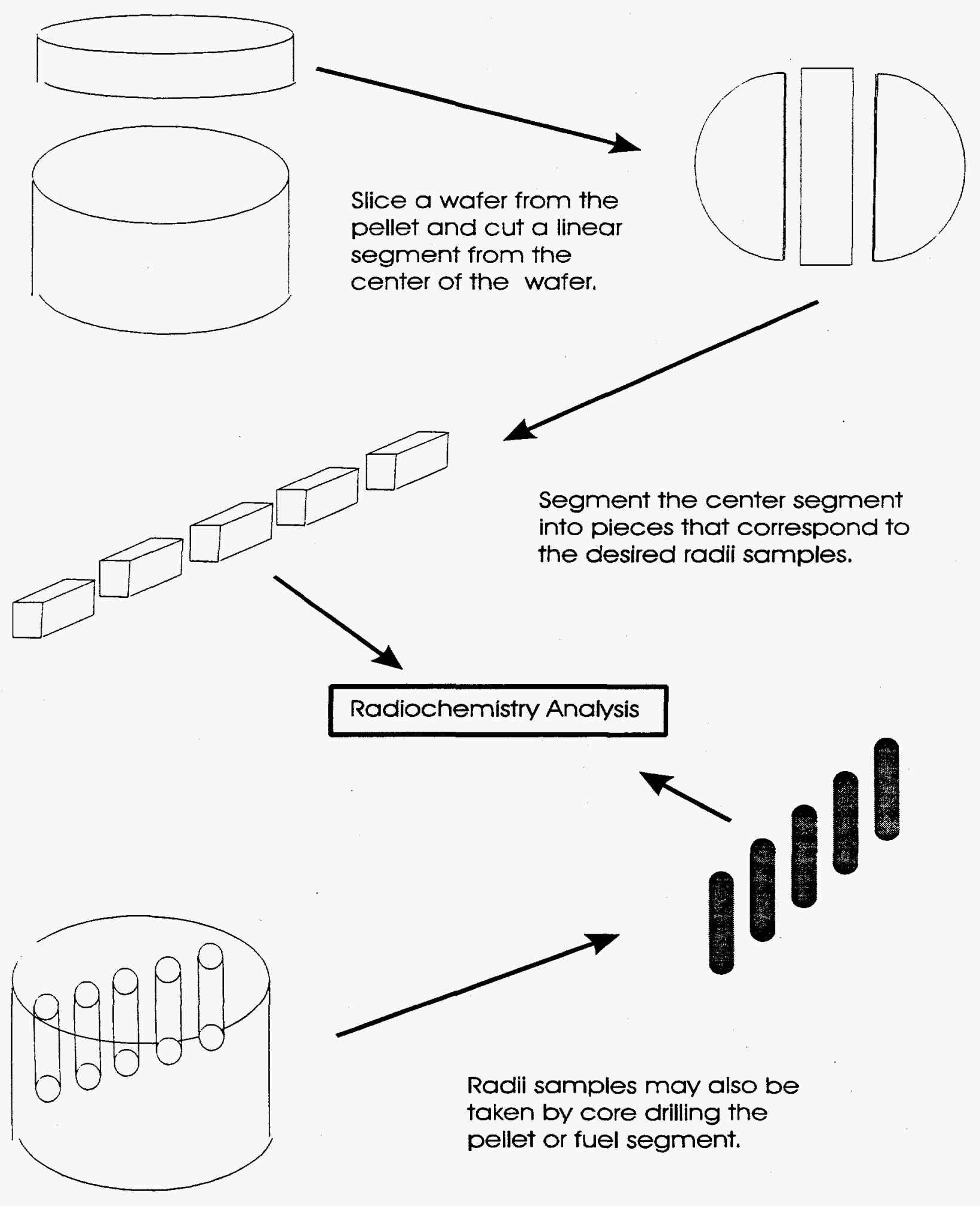

Fig. 9. Pellet segmenting for radiochemistry. 
cross contamination. Each sample will be stored in a separate labeled container noting its radial location and source pellet. Each sample will then be dissolved in an appropriate chemical solution.

Gamma counting of the dissolved samples will be performed, along with radiochemical operations to determine the concentrations of uranium, plutonium, gallium, and selected fission products. In addition, the remains of at least one of the segmented or cored pellets will be weighed and dissolved in a fresh solution of the same composition as before. This solution will be analyzed for the same isotopes as above. The original pellet weight will be used to scale the inventories so that an absolute aggregate inventory (or a reasonable approximation) of the pellet is obtained. The results of the radial sampling can then be used to construct isotope distributions within the pellet and estimate the burnup.

\subsection{GALLIUM CALIBRATION}

Because analysis for gallium is not a routine part of fuels examination, the project will take care to see that the proper calibrations and tests have been undertaken so that a credible search for trace amounts of gallium is truly possible. Previous PIE examinations of the lower-burnup MOX fuel will have established best practices so that this PIE effort will not have to engage in extensive gallium calibrations or comparisons. The gallium results of preirradiation fuel samples will be available to the project, thus minimizing the amount of gallium testing that needs to be done on the fuel.

\subsection{CERAMOGRAPHIC AND SEM MOUNTS}

The selected fuel segments or portions of pellets will be mounted and, if necessary, cut to an appropriate size for ceramographic polishing and examination. The specimens will be photographed and documented; project management will be notified if serious fuel defects, such as large internal voids, are noted. Selected portions of a pellet may be prepared for scanning electron microscope examination and elemental surface distribution mapping. The detail required by this task will depend on the results of the radiochemical operations, the radiation levels of the sample, and the limitations of the SEM. Radiation levels may preclude SEM examination of entire fuel pellet cross sections. If this is the case, project management will be consulted before proceeding as the information obtained may not be worth the cost.

Photographs of the ceramographic sections will be digitized and digitally stored, if possible; the detail of the digital storage may not be adequate for this task and should be evaluated with the equipment available at the time.

\subsection{CLADDING}

The degree to which gallium has intruded into the clad will first be evaluated by means of metallographic examinations. Depending upon these results, the extent of clad testing as described in the following paragraphs may be modified by the ORNL Test Project Office to a level that is commensurate with the degree of the gallium migration into the clad. 
Cladding samples will be prepared by cutting the Zircaloy cladding into pieces as required for the analysis. Each metallographic mount will be visually examined for signs of surface reactions and mechanical defects, such as cracking and penetrations. Any such defects will be photographed and documented. SEM examination of the samples will be made as radiation levels permit. Weighed samples will be dissolved or leached in appropriate chemical solutions and the gallium content determined.

Tensile and hardness specimens will be prepared and the appropriate testing conducted. Surface cleaning of the samples may be required to limit the alpha contamination of the testing equipment. Depending on the course of the experiment, other mechanical tests may be made in addition to, or instead of, the above tests (the results of other PIE work and gallium experiments may influence the desired mechanical tests). 


\section{STORAGE OF CAPSULE CONTENTS}

All fuel pellets, cladding, and specified pieces of the fuel pins will be stored in suitably numbered hot-cell containers unless the project requests that they be discarded during the PIE task. A list of the PIE objects, their locations, their disposition, and the personnel requesting their use will be kept. The identification and contents of each container will be recorded in a hot-cell logbook and in the test engineer's laboratory notebooks. The facility manager will be kept aware of the containers and their contents, especially their fissile material. 


\section{DOCUMENTATION}

Observations, photographs, videotapes, digital files, and other data will be recorded on the appropriate medium and documented in ORNL laboratory notebooks as the examination proceeds. Moreover, a copy of this PIE plan will be kept as a working, marked-up copy, and any changes to this plan will be recorded and dated as they occur during the PIE. Progress of the PIE effort will be described in the project monthly reports. A preliminary report will be prepared as soon as practical after the capsule assemblies have been examined. The final results of this PIE examination will be documented in an ORNL topical report. 


\section{COSTS AND SCHEDULES}

The cost and schedules for the PIE are shown in Fig. 10. A preliminary report will be delivered approximately 3 months after the load in of the Test Capsule set. A Final PIE report will be delivered approximately 16 months after the receipt of the Test Capsule set.

The FY 1999-2002 costs for the early and intermediate PIEs, and for the final burnup PIE, are shown in Table 5.

Table 5. Estimated PIE costs (\$K)

\begin{tabular}{|c|r|r|r|l||}
\hline Year & $\begin{array}{c}\text { PIE } \\
\text { Cost }\end{array}$ & $\begin{array}{c}\text { Equipment } \\
\text { Cost }\end{array}$ & $\begin{array}{c}\text { Yearly } \\
\text { Total }\end{array}$ & \multicolumn{1}{|c|}{ Comments } \\
\hline \hline 1999 & $\$ 900$ & 0 & $\$ 900$ & First PIE (8 GWd/MT) \\
\hline 2000 & $\$ 900$ & $\$ 200$ & $\$ 1,100$ & $\begin{array}{l}\text { Intermediate PIE; Purchase } \\
\text { Fission Gas Apparatus }\end{array}$ \\
\hline 2001 & $\$ 1,300$ & 0 & $\$ 1,300$ & Begin Final PIE \\
\hline 2002 & $\$ 600$ & 0 & $\$ 600$ & Complete Final PIE \\
\hline
\end{tabular}


PIE for 30-GWd/MT Burnup Fuel

\begin{tabular}{|c|c|c|c|c|c|c|c|c|c|c|c|c|c|c|c|}
\hline \multirow{2}{*}{ Task Name } & \multirow{2}{*}{ Start } & \multirow{2}{*}{ End } & \multirow{2}{*}{ Duration } & \multirow{2}{*}{ Cout } & \multicolumn{4}{|c|}{2001} & \multicolumn{4}{|c|}{2002} & \multicolumn{3}{|c|}{2003} \\
\hline & & & & & Q1 & Q2 & 03 & Q4 & a1 & Q2 & 03 & 04 & Q1 & $\mathbf{0 2}$ & Q33 \\
\hline 1.0 FInAl PIE $30 \mathrm{GWO} / \mathrm{MT}$ & OAFebio1 & $30 \mathrm{nmoy} 22$ & $336.00 \mathrm{~d}$ & $\$ 1,686,000,00$ & & & & & 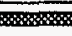 & 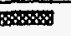 & & & & & \\
\hline 1.1 PIE Prolect & $01 / \mathrm{Feb} / 01$ & 30/May/02 & $336.00 \mathrm{~d}$ & $\$ 40,000,00$ & & & & & & 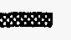 & & & & & \\
\hline 1.1.1 Safoty and Criticality Roviow & 01/Fab/01 & 06/Mar/01 & $23.00 \mathrm{~d}$ & $\$ 10,000.00$ & & & & & & & & & & & \\
\hline 1.1.2 Interim Reporting & O1/Fob/01 & 30/May/02 & $336.00 \mathrm{~d}$ & $\$ 40,000.00$ & & & & & & & & & & & \\
\hline 1.1.3 Proliminary PIE Repart & 01/Mar/01 & $30 /$ May $/ 01$ & $64.00 \mathrm{~d}$ & $\$ 15,000.00$ & & & & & & & & & & & \\
\hline 1.1.4 Final PIE Report & $01 / 0 c t / 01$ & 30/May/02 & $168.00 \mathrm{~d}$ & $1116,000.00$ & & & & & & & & & & & \\
\hline 1.1.5 Hot Coll & O1/Mar/01 & $30 /$ May/02 & $317.00 \mathrm{~d}$ & $\$ 225,000,00$ & & & & & & & & & & & \\
\hline 1.1.6 Wasto Handling & 01/Mar/01 & $30 / \mathrm{May} / 02$ & $317.00 \mathrm{~d}$ & $\$ 35,000.00$ & & & & & & & & & & & \\
\hline 1.2 Load in and Preparation & 01/Mar/o1 & 02/Marro1 & $2.00 \mathrm{~d}$ & $\$ 7,000.00$ & 1 & & & & & & & & & & \\
\hline 1.2.1 Capsulo Load in & 01/Mar/01 & 01/Mar/01 & $1.00 \mathrm{~d}$ & $\$ 5,000.00$ & & & & & & & & & & & \\
\hline 1.2.2 Cask Decon & 02/Mar/01 & $02 / \mathrm{Mar} / 01$ & $1.00 \mathrm{~d}$ & $\$ 2,000.00$ & & & & & & & & & & & \\
\hline 1.3 initial Inspection & $05 /$ Mar/01 & O9Mmario1 & $5.00 \mathrm{~d}$ & $\$ 15,000.00$ & I & & & & & & & & & & \\
\hline 1.3.1 Visual Inspection (4) & 05/Mar/01 & 06/Mar/01 & $2.00 \mathrm{~d}$ & $\$ 6,000.00$ & 1 & & & & & & & & & & \\
\hline 1.3.2 Dimensional Inepoction (4) & 07/Mar/01 & 09/Mar/01 & $3.00 \mathrm{~d}$ & $99,000.00$ & 1 & & & & & & & & & & \\
\hline 1.4 Capsule Gamma Scan & 12/Marro1 & 30/Aprio1 & $36.00 \mathrm{~d}$ & $\$ 64,000.00$ & & 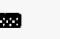 & & & & & & & & & \\
\hline 1.4.1 Propare and 4 Mount Capauloe & 12/Mar/01 & 13/Mar/01 & $2.00 \mathrm{~d}$ & $\$ 6,000,00$ & 1 & & & & & & & & & & \\
\hline 1.4.2 Scan 4 Capsules & 14/Mor/O1 & 02/Apr/01 & $14.00 \mathrm{~d}$ & $\$ 43,000.00$ & & & & & & & & & & & \\
\hline 1.4.3 GS Data Analysis & $03 / A p r / 01$ & 30/Apr/01 & $20.00 \mathrm{~d}$ & $\$ 15,000.00$ & & & & & & & & & & & \\
\hline 1.5 Open Capsules & 03/Apr/OS & 201Aprio1 & $14.00 \mathrm{~d}$ & $\$ 4,000.00$ & & $\boldsymbol{a}$ & & & & & & & & & \\
\hline 1.5.1 Preparation & 03/Apr/01 & 04/Apr/01 & $2.00 \mathrm{~d}$ & $\$ 6,000.00$ & & & & & & & & & & & \\
\hline 1.5.2 Remove SS Containment (4) & 05/Apr/01 & 20/Apr/01 & $12.00 \mathrm{~d}$ & $\$ 38,000,00$ & & & & & & & & & & & \\
\hline 1.6 Fuel Pins & 23/Apr101 & $16 /$ May/01 & $18.00 \mathrm{~d}$ & $\$ 64,000.00$ & & 心 & & & & & & & & & \\
\hline 1.6 .1 Inspection (4) & 23/Apr/01 & 26/Apr/01 & $4.00 \mathrm{~d}$ & $\$ 12.000 .00$ & & 1 & & & & & & & & & \\
\hline 1.6.2 Fission Gas Mogsurement & $27 /$ Apr/O1 & 03/May/01 & $5.00 \mathrm{~d}$ & $\$ 24,000.00$ & & ! & & & & & & & & & \\
\hline 1.6.3 Remove Fuel (4) & O4/May/01 & 16/May/01 & $9.00 \mathrm{~d}$ & $\$ 28,000.00$ & & - & & & & & & & & & \\
\hline 1.7 Fuel Examination & 17 Mayro1 & 22May/01 & $4.00 \mathrm{~d}$ & $\$ 12,000,00$ & & ' & & & & & & & & & \\
\hline 1.7 .1 Inspect Fuel Segments (16) & 17/May/01 & 22/Moy/01 & $4.00 \mathrm{~d}$ & $\$ 12,000.00$ & & I & & & & & & & & & \\
\hline 1.8 Fuel Analysis & 23/May/01 & $17 / 0 \mathrm{ct} / 01$ & $103.00 \mathrm{~d}$ & $\$ 324,000.00$ & & & & & & & & & & & \\
\hline 1.8.1 Propare 16 Ceramographic Mounts & 23/May/01 & $09 / \mathrm{Ju} / \mathrm{01}$ & $32.00 \mathrm{~d}$ & $\$ 101,000.00$ & & & & & & & & & & & \\
\hline 1.8.2 Prepare 16 Fuel Segments for GS & $10 / \mathrm{Jul} / 01$ & $16 / \mathrm{Jul} / 01$ & $5.00 \mathrm{~d}$ & $125,000.00$ & & & ! & & & & & & & & \\
\hline 1.8.3 Gamma Scan 16 Fuel Segments & $17 / J u / 101$ & 13/Aun/01 & $20.00 d$ & 181.000 .00 & & & & & & & & & & & \\
\hline 1.8.4 GS Data Analysia & 14/Aur/01 & 29/Aur/01 & $12.00 \mathrm{~d}$ & $\$ 10,000.00$ & & & घ & & & & & & & & \\
\hline 1.8.6 Cut Up or Core 16 Fuol Pin Segments & $30 / A \ln / 01$ & $17 / 0$ ct/01 & $34.00 \mathrm{~d}$ & $\$ 107.000 .00$ & & & & & & & & & & & \\
\hline 1.9 Fuel Radiochemistry & $18 / 0 \mathrm{ct} / 01$ & 30/Jan/02 & $71.00 \mathrm{~d}$ & $\$ 206,000.00$ & & & & & & & & & & & \\
\hline 1.9.1 Prepare Solutions & $18 / 0 \mathrm{ct} / 01$ & $24 / 0 c t / 01$ & $5.00 \mathrm{~d}$ & $\$ 16,000.00$ & & & & I & & & & & & & \\
\hline 1.9.2 Analysis & $25 / 0 \mathrm{ct} / 01$ & $20 / 0$ ec/01 & $40.00 \mathrm{~d}$ & $1160,000.00$ & & & & & & & & & & & \\
\hline 1.9.3 Fuel RC Data Computation & $02 / \operatorname{Jan} / 02$ & $30 / \operatorname{Jan} / 02$ & $20.00 \mathrm{~d}$ & $\$ 30,000.00$ & & & & & & & & & & & \\
\hline 1.10 Clad Analysis & $2510 \mathrm{ct} 01$ & $21 / F$ eb/02 & $81.00 \mathrm{~d}$ & $\$ 227,000.00$ & & & & & & & & & & & \\
\hline 1.10.1 Prepare 16 Metallographic Mounts & $25 / 0 a t / 01$ & $10 / \mathrm{Dec} / 01$ & $32.00 \mathrm{~d}$ & 1101.000 .00 & & & & & & & & & & & \\
\hline 1.10.2 Cut Up 32 Clad Sections & $11 /$ Dec/01 & $02 / \operatorname{Jan} / 02$ & $15.00 \mathrm{~d}$ & $\$ 32,000.00$ & & & & & & & & & & & \\
\hline 1.10 .3 Clad SEM (16) & $07 / \operatorname{Jan} / 02$ & $21 /$ Fob/02 & $32.00 \mathrm{~d}$ & $\$ 94,000,00$ & & & & & $=$ & & & & & & \\
\hline 1.11 Clad Radiochemsitry & $03 / \mathrm{Jan} / 02$ & $31 / \mathrm{Jan} / 02$ & $20.00 \mathrm{~d}$ & $\$ 69,000.00$ & & & & & 唡 & & & & & & \\
\hline 1.11.1 Propare Solutions (16) & $03 / \operatorname{Jan} / 02$ & $04 / \mathrm{Jan} / 02$ & $2.00 \mathrm{~d}$ & $\$ 7,000.00$ & & & & & & & & & & & \\
\hline 1.11.2 Clad Solution Analysis & $07 /$ Jan $/ 02$ & $16 / \operatorname{Jan} / 02$ & $8.00 \mathrm{~d}$ & $32,000,00$ & & & & & & & & & & & \\
\hline 1.11.3 Clad RC Data Computation & $17 / \operatorname{San} / 02$ & $31 / \operatorname{Ian} / 02$ & $10.00 \mathrm{~d}$ & $88,000,00$ & & & & & - & & & & & & \\
\hline 1.11.4 SS Clad Analysis & $17 / \operatorname{Jan} / 02$ & 18/Jan/02 & $2.00 \mathrm{~d}$ & $\$ 8,000.00$ & & & & & 1 & & & & & & \\
\hline 1.11.5 Spring \& Plenum Ga Analysis & $22 / \operatorname{Jan} / 02$ & $25 / \mathrm{Jan} / 02$ & $4.00 \mathrm{~d}$ & $\$ 14,000.00$ & & & & & I & & & & & & \\
\hline 1.12 Mechanlcal Testing & $07 / \mathrm{Jan} / 02$ & 10/Apr/02 & $66.00 \mathrm{~d}$ & $\$ 214,000.00$ & & & & & & & & & & & \\
\hline 1.12.1 Machine Specimens - 16 Tansilie, 16 Hardness & $07 / \operatorname{Jan} / 02$ & 29/Mar/O2 & $58.00 \mathrm{~d}$ & $\$ 170,000.00$ & & & & & & & & & & & \\
\hline 1.12.2 Tensile Testing -16 Specimens & $01 / \mathrm{Apr} / 02$ & 04/Apr/02 & $4.00 \mathrm{~d}$ & $\$ 22,000.00$ & & & & & & & & & & & \\
\hline 1.12.3 Hardnoss Tosting - 16 Spocimens & 05/Apr/02 & 10/Apr/02 & $4.00 \mathrm{~d}$ & $22,000.00$ & & & & & & & & & & & \\
\hline
\end{tabular}

Printed: 16/Sop/97

Printed:

Fig. 10. Costs and schedule for the 30-GWd/MT PIE. 


\section{REFERENCES}

1. S. A. Hodge, Fissile Materials Disposition Program Light Water Reactor Mixed Oxide Fuel Irradiation Test Project Plan, Oak Ridge National Laboratory, Oak Ridge, Tenn., May 28, 1997.

2. B. S. Cowell, Light Water Reactor (LWR) Mixed Oxide Fuel Kickoff Meeting October 8-9, 1996, ORNL/MDL/LTR-59, Oak Ridge National Laboratory, Oak Ridge, Tenn., November 26, 1996.

3. R. N. Morris, MOX Capsule Post-Irradiation Examination Vol I: Test Plan for Low Burnup Fuel, ORNL/MDL/LTR-93, Oak Ridge National Laboratory, Oak Ridge, Tenn., July 1997.

4. S. A. Hodge, Capsule Design Issues Meeting Task 7.2 LWR In-Pile Testing March 12, 1997, Oak Ridge, Tennessee, ORNL/MD/LTR-72, Oak Ridge National Laboratory, Oak Ridge, Tenn., 1997.

5. Guidebook on Non-destructive Examination of Water Reactor Fuel, Technical Reports Series No. 322, International Atomic Energy Agency, Vienna, 1991.

7. J. F. W. Markgraf et al., Non-destructive Determination of Fission Gas Release in Ramp-Tested LWR Fuel Rods, IWGFPT/22, IAEA, Vienna, 1996.

8. R. N. Morris, MHTGR Fissile and Fertile Particle Burnup Determination by Gamma Spectroscopy, ORNL/TM-12310, Oak Ridge National Laboratory, Oak Ridge, Tenn., February 1994. 
ORNL/MD/LTR-93

Level 2

\section{INTERNAL DISTRIBUTION}

\begin{aligned} & 1. \\ & 2. B. S. Cowell \\ & 3. R. H. Fowler \\ & 4. D. W. Heatherly \\ & 5. S. A. Hodge \\ & 6. M. A. Kuliasha \\ & 7. S. B. Ludwig \\ & 8. W. A. Miller \\ & 10. K. R. Thoms \\ & 11. ORNL Laboratory Records (OSTI) \\ & \hline\end{aligned}

\section{EXTERNAL DISTRIBUTION}

12-14. K. Chidester, Los Alamos National Laboratory, P.O. Box 1663, MS-E502, Los Alamos, NM 87545

15. P. T. Rhoads, U.S. Department of Energy, MD-3, 1000 Independence Avenue SW, Forrestal Building 6G-050, Washington, DC 20585

16-21. J. M. Ryskamp, Idaho National Engineering and Environmental Laboratory, MS 3885, P.O. Box 1625, Idaho Falls, ID 83415-3885

22. R. H. Steele, MPR Associates Inc., 320 King Street, Alexandria, VA 22314-3238

23-25. J. Thompson, U.S. Department of Energy, MD-3, 1000 Independence Avenue SW, Forrestal Building 6G-050, Washington, DC 20585. 